\title{
Głęboka odpowiedź molekularna po podaniu dazatynibu w 3. linii terapii u chorego na przewlekłą białaczkę szpikową w fazie przewlekłej
}

\author{
Deep molecular response after $3^{\text {rd }}$-line dasatinib treatment \\ in patient with chronic myelogenous leukemia in chronic phase
}

\author{
Maria Lewandowska ${ }^{1}$, Michał Gniot ${ }^{1}$, Błażej Ratajczak ${ }^{1}$, \\ Małgorzata Jarmuż-Szymczak ${ }^{1,2}$, Krzysztof Lewandowski ${ }^{1}$ \\ ${ }^{1}$ Katedra i Klinika Hematologii i Transplantacji Szpiku, Uniwersytet Medyczny im. Karola Marcinkowskiego, \\ Poznań \\ ${ }^{2}$ Instytut Genetyki Człowieka, Polska Akademia Nauk ${ }^{1}$
}

\begin{abstract}
Streszczenie
Niepowodzenie terapii imatynibem (IM) u chorych na przewlekta biataczke szpikowa (CML) $w$ fazie przewlektej jest wskazaniem do rozpoczecia terapii 2. linii inhibitorami kinazy tyrozynowej II generacji. Niestety, u czéści z nich ponownie obserwuje sie objawy nietolerancji/nieskuteczności TKI II generacji. W pracy przedstawiono przypadek chorego na CML w fazie przewlektej z opornościa na IM, u którego w trakcie leczenia nilotynibem stwierdzono wystapienie objawów toksyczności hematologicznej (matoptytkowość 3. stopnia wg CTCAE), a następnie oporności mutacyjnej (H396P KD BCR-ABL1). Na podstawie przewidywanego profilu skuteczności TKI II generacji in vitro zdecydowano o dalszym leczeniu dazatynibem w dawce $100 \mathrm{mg} / \mathrm{raz} /$ dobe doustnie. Catkowita odpowiedź cytogenetyczna uzyskano po 6 miesiacach, a wieksza odpowiedź molekularna — po 9 miesiacach leczenia. W kolejnych miesiacach obserwowano stata poprawe jakości odpowiedzi molekularnej. W ocenie przeprowadzonej w czerwcu 2014 roku potwierdzono uzyskanie gtebokiej odpowiedzi molekularnej. Co wiecej, potwierdzono jej utrzymywanie sie w kolejnych ocenach.
\end{abstract}

Słowa kluczowe: przewlekła białaczka szpikowa, głęboka odpowiedź molekularna, dazatynib w 3. linii

Hematologia 2015; 6, 2: 213-217

\begin{abstract}
Imatinib (IM) therapy failure in patients with chronic myelogenous leukemia (CML) in the chronic phase is an indication for second-line treatment with second generation of tyrosine kinase inhibitors ( $2^{\text {nd }}$ generation of TKI). Unfortunately, the symptoms of therapy intolerance/failure are observed in part of them. We present a case of CML patient in chronic phase with IM-resistance in whom hematologic toxicity was observed during nilotinib treatment (thrombocytopenia grade 3 acc. CTCAE), as well as the symptoms of mutational TKI-resistance (H396P KD BCR-ABL) thereafter. On the basis of $2^{\text {nd }}$ generation of TKI efficacy in vitro profile, a decision about dasatinib therapy
\end{abstract}

Adres do korespondencji: Krzysztof Lewandowski, Katedra i Klinika Hematologii i Transplantacji Szpiku, Uniwersytet Medyczny im. Karola Marcinkowskiego, ul. Szamarzewskiego 84, 60-569 Poznań, faks: 618549356 , e-mail: krzysztof.lewandowski@skpp.edu.pl 
in a dose of $100 \mathrm{mg}$ orally daily was undertaken. Complete cytogenetic response was obtained after 6 months, and major molecular response after 9 months of therapy. A follow-up revealed continuous improvement in quality of molecular response. In June 2014 deep molecular response was obtained. Moreover, their persistence during consecutive months was also confirmed.

Key words: chronic myelogenous leukemia, deep molecular response, dasatinib $3^{\text {rd }}$-line

Hematologia 2015; 6, 2: 213-217

\section{Wprowadzenie}

Zastosowanie leczenia inhibitorami kinazy tyrozynowej BCR-ABL1 (TKI, tyrosine kinase inhibitors) II generacji umożliwia uzyskanie całkowitej odpowiedzi cytogenetycznej (CCyR, complete cytogenetic response) u 40-60\% chorych na przewlekłą białaczkę szpikową (CML, chronic myelogenous leukaemia) z objawami oporności/nietolerancji imatynibu (IM) [1]. Niestety, także w trakcie podawania leków $z$ tej grupy u około $50 \%$ chorych ponownie stwierdza się objawy nietolerancji/nieskuteczności terapii [2-5]. Wystąpienie objawów nietolerancji leczenia zmusza do czasowego zaprzestania podawania lub zmniejszenia dawki stosowanego leku, co wiąże się $z$ obniżeniem intensywności prowadzonej terapii, a w końcowym efekcie prowadzi do zmniejszenia prawdopodobieństwa uzyskania optymalnej odpowiedzi. Stwierdzenie oporności na IM może wynikać $z$ obecności mutacji $\mathrm{w}$ obrębie sekwencji kodującej strukturę domeny kinazowej (KD, kinase domain) kinazy tyrozynowej $B C R-A B L 1$ lub oporności niemutacyjnej komórek CML. W tym ostatnim przypadku przyczyną niepowodzenia terapii jest zmniejszenie ekspozycji komórek białaczkowych na lek, między innymi poprzez upośledzenie dokomórkowego transportu leku w wyniku obniżonej aktywności organicznego ludzkiego transportera kationów (hOCT1, human organic cation transporter type 1) czy jego szybkie usuwanie $z$ komórki w przypadku wysokiej ekspresji genu oporności wielolekowej (MDR, multidrug resistance genes). Przyczyną niepowodzenia leczenia może być także zbyt niskie stężenie wolnej frakcji leku we krwi w wyniku wzrostu stężenia kwaśnej glikoproteiny 1 czy też obecność w komórkach białaczkowych dodatkowych, niezależnych od kinazy tyrozynowej BCR-ABL, szlaków przewodzenia sygnału proliferacyjnego $[6,7]$.

Ostatnio wykazano, że u chorych z opornością na TKI sekwencyjne stosowanie inhibitorów może prowadzić do selekcji klonalnej choroby oraz pojawienia się klonów opornych [8, 9]. Jej wystąpienie wiąże się z ryzykiem niepowodzenia 2 . linii terapii za pomocą TKI [10]. Poniżej przedstawiono przebieg kliniczny choroby u chorego na CML w fazie przewlekłej $z$ opornością na IM oraz nilotynib, leczonego dazatynibem w 3 . linii terapii.

\section{Opis przypadku}

Pacjent $\mathrm{w}$ wieku 46 lat, $\mathrm{z}$ rozpoznaną $\mathrm{w} 2003$ roku fazą przewlekłą CML (transkrypt $B C R-A B L 1$ e14a2 [b3a2], ryzyko pośrednie, wskaźnik Sokala 0,9), został przyjęty do kliniki w październiku 2006 roku. W okresie poprzedzającym (od października 2003 do maja 2005 r.) z powodu znacznej leukocytozy oraz organomegalii był leczony w ośrodku terenowym hydroksymocznikiem (HU, hydroxyurea) w dawce 1000-1500 mg/dobę doustnie. W połowie maja 2005 roku został zakwalifikowany do leczenia IM w dawce $400 \mathrm{mg}$ /dobę doustnie. Po 18 miesiącach terapii stwierdzono oporność (brak odpowiedzi cytogenetycznej). Od marca 2007 roku chory był leczony nilotynibem w dawce 2 razy $400 \mathrm{mg} /$ dobę doustnie. Zgodnie $\mathrm{z}$ obowiązującymi wytycznymi National Comprehensive Cancer Network (NCCN), z powodu wystąpienia objawów toksyczności hematologicznej (nawracająca małopłytkowość mimo przerw w leczeniu) 3. stopnia według Common Terminology Criteria for Adverse Events (CTCAE), dawkę leku zmniejszono do $400 \mathrm{mg}$ /dobę [11, 12]. W wykonanym po 18 miesiącach (w sierpniu 2008 r.) kontrolnym badaniu cytogenetycznym potwierdzono brak większej odpowiedzi cytogenetycznej (12/25 metafaz Philadelphia-dodatnich - $\mathrm{Ph}(+) ; 48 \%)$. Przeprowadzona po 6 miesiącach kolejna ocena cytogenetyczna potwierdziła uzyskanie większej odpowiedzi cytogenetycznej (1/28 metafaz $\mathrm{Ph}(+), 3 \%)$. Ocena ilościowa wykazała ilość transkryptu BCR-ABL1 IS (international scale) 0,595\%. W kwietniu 2010 roku podawanie leku czasowo wstrzymano $z$ powodu wystąpienia objawów toksyczności wątrobowej (stężenie aminotransferazy alaninowej [ALAT, alanine aminotransferase] $136 \mathrm{jm} . / \mathrm{ml}$, toksyczność 2. stopnia wg CTCAE). Przeprowadzona w marcu 2011 roku ponowna ilościowa ocena ilości transkryptu potwierdziła nieuzyskanie większej odpowiedzi molekularnej (MMR, major molecular response) (ilość transkryptu $B C R$ -ABL1 IS 4,16\%). Zdecydowano o wykonaniu ba- 


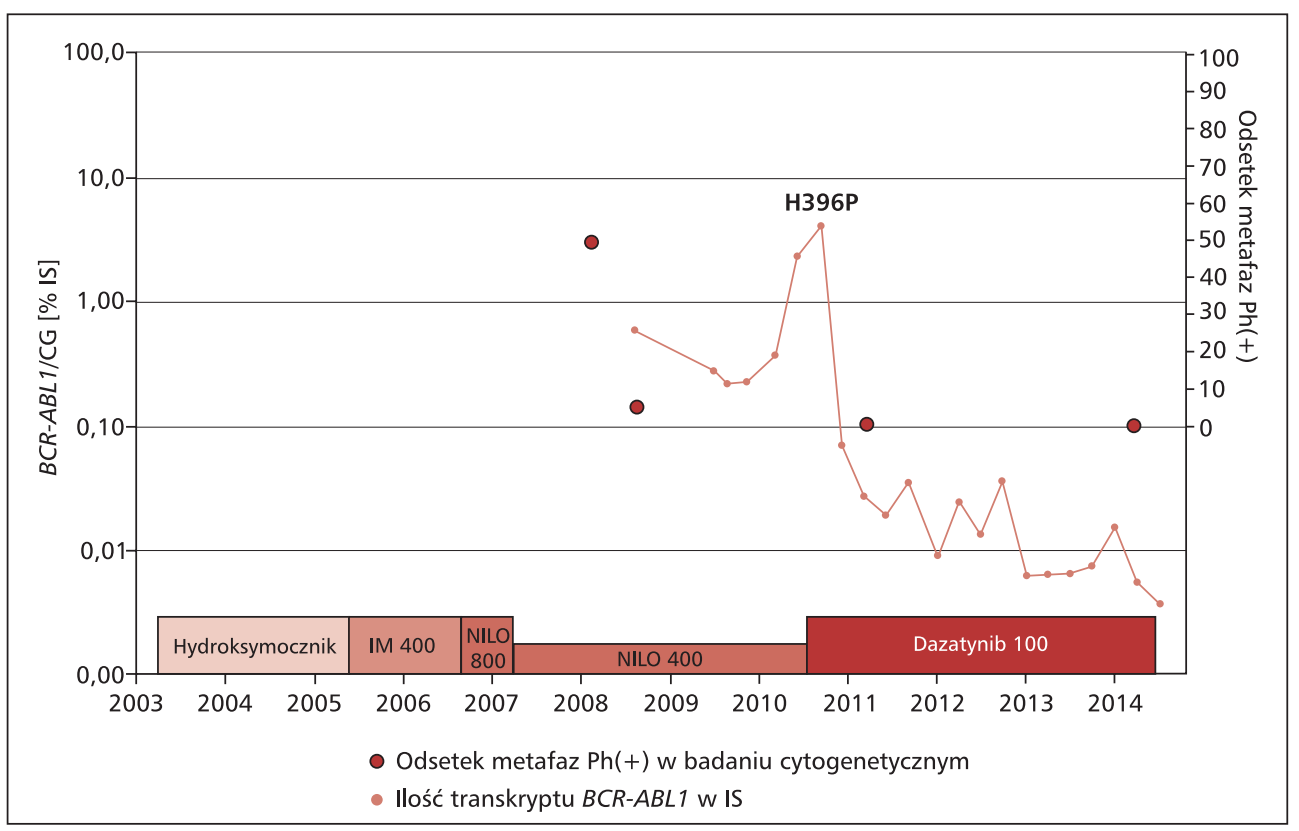

Rycina 1. Odpowiedzi cytogenetyczna i molekularna w trakcie zastosowanego leczenia; IS — skala międzynarodowa; $\mathrm{Ph}+$ - t(9;22)(q34; q11); IM — imatynib, NILO — nilotynib

Figure 1. Cytogenetic and molecular responses during treatment applied; IS — international $\mathrm{scale} ; \mathrm{Ph}+-\mathrm{t}(9 ; 22)$ (q34; q11); IM - imatinib, NILO - nilotinib

dania na obecność mutacji KD $B C R-A B L 1$ metodą sekwencjonowania. Szczególowa analiza sekwencji potwierdziła obecność mutacji H396P genu BCR$-A B L 1$. Na podstawie przewidywanego profilu skuteczności TKI zdecydowano o dalszym leczeniu dazatynibem w dawce $100 \mathrm{mg} / \mathrm{raz} /$ dobę doustnie [13-15]. Całkowitą odpowiedź cytogenetyczną (CCyR, complete cytogenetic response) uzyskano po 6 miesiącach stosowania leku (wrzesień 2011 r., kariotyp 46,XY[32]). Wykonana po 3 miesiącach ocena odpowiedzi molekularnej potwierdziła uzyskanie MMR z ilością kopii transkryptu $B C R$ -ABL1 IS 0,018\%. W kolejnych miesiącach terapii obserwowano stałą poprawę jakości odpowiedzi molekularnej. W ocenie przeprowadzonej w czerwcu 2014 roku potwierdzono uzyskanie głębokiej odpowiedzi molekularnej, a w kolejnych ocenach przeprowadzanych co 3 miesiące - jej utrzymywanie się (ryc. 1). Przeprowadzona we wrześniu 2014 roku rutynowa ocena cytogenetyczna wykazała utrzymywanie się CCyR oraz obecność aberracji cytogenetycznych w komórkach Ph-ujemnych - kariotyp 47,XY,+Y[2]/45,XY,-21[6]/46,XY[23].

\section{Dyskusja}

W jednym $z$ badań wykazano, że u $56 \%$ chorych na CML w fazie przewlekłej po niepowodzeniu terapii za pomocą IM można, techniką sekwencjonowania, wykazać obecność mutacji onkogenu $B C R-A B L 1$ [16]. Większość tych pacjentów jest wrażliwa na TKI II generacji — nilotynib [17]. W innym $z$ badań poświęconych temu zagadnieniu obecność mutacji onkogenu $B C R-A B L 1$ potwierdzono u $39 \%$ ocenianych chorych. Okazało się jednak, że u $14 \% \mathrm{z}$ badanych ich występowaniu towarzyszyła obecność dodatkowych aberracji cytogenetycznych w klonie $\mathrm{Ph}(+)$ [18]. Z tego powodu, zgodnie $\mathrm{z}$ wytycznymi NCCN, dokonując wyboru leczenia 2 . linii u chorych $z$ opornością na IM, należy za każdym razem wykonać badanie kariotypu w kierunku ewentualnej ewolucji klonalnej choroby, a także ocenić stan mutacyjny KD BCR-ABL1. Badanie na obecność mutacji KD $B C R-A B L 1 \mathrm{w}$ trakcie terapii 2. linii należy również przeprowadzić w przypadku stwierdzenia odpowiedzi nieoptymalnej lub wzrostu ilości transkryptu $B C R-A B L 1$ o 0,5-1 log [11].

Zastosowanie nilotynibu w 2 . linii leczenia chorych na CML w fazie przewlekłej z opornościąnietolerancją IM pozwala na uzyskanie 3-letniego przeżycia wolnego od progresji (PFS, progression-free survival) choroby u 55\% pacjentów [4, 10]. W badaniu 2. fazy (CAMN107A2101), poświęconym określeniu skuteczności i bezpieczeństwa stosowania nilotynibu podawanego w dawce 2 razy $400 \mathrm{mg} /$ dobę chorym po niepowodzeniem terapii 
lub z nietolerancją IM, wykazano, że po 6 miesiącach leczenia większą odpowiedź cytogenetyczną uzyskuje jedynie $48 \%$ pacjentów, a szacowane PFS oraz przeżycie całkowite (OS, overall survival) po 48 miesiącach terapii wynoszą, odpowiednio, $57 \%$ i $78 \%$. $Z$ wyjątkiem nielicznych przypadków lek okazał się skuteczny - zarówno u chorych z opornością mutacyjną na IM, jak i u pacjentów $z$ opornością niemutacyjną na ten lek.

W trakcie stosowania nilotynibu objawy toksyczności niehematologicznej miały nasilenie łagodne lub umiarkowane. Także toksyczność hematologiczna leku była akceptowalna - w grupie tej małopłytkowość lub granulocytopenię 3.-4. stopnia obserwowano $\mathrm{u}$, odpowiednio, $30 \%$ i $32 \%$ pacjentów [19, 20]. Właśnie wystąpienie małopłytkowości 3. stopnia według CTCAE było powodem zmniejszenia dawki nilotynibu $\mathrm{w}$ prezentowanym przypadku. Nilotynib cechuje jedynie minimalna krzyżowa nietolerancja w odniesieniu do IM. $Z$ tego powodu u znaczącej części chorych po niepowodzeniu terapii/z nietolerancją leczenia IM udaje się uzyskać CCyR, a u dużej części - także MMR po podaniu leku w dawce 2 razy $400 \mathrm{mg} /$ dobę [21].

$\mathrm{W}$ badaniach in vitro dowiedziono, że w stężeniach terapeutycznych nilotynib pozostaje nieaktywny lub jest tylko miernie aktywny wobec niektórych klonów komórkowych $z$ mutacjami genu $B C R-A B L 1$, w tym $\mathrm{Y} 253 \mathrm{~F} / \mathrm{H}, \mathrm{E} 255 \mathrm{~K} / \mathrm{V}$ oraz F359V/C/I. Nilotynib nie wykazuje właściwości inhibitorowych wobec mutacji H396P. Zastosowanie tego leku nie jest również skuteczne w przypadku obecności mutacji T315I genu BCR-ABL1 [15].

Podobną do nilotynibu skuteczność kliniczną u chorych na CML w fazie przewlekłej opornych/nietolerujących IM wykazuje inny TKI II generacji - dazatynib. W badaniu START-C przeprowadzonym $\mathrm{u}$ chorych $\mathrm{w}$ fazie przewlekłej CML potwierdzono, że u $90 \%$ pacjentów z opornością/nietolerancją IM możliwe jest uzyskanie całkowitej odpowiedzi hematologicznej (CHR, complete hematologic response), a u 52\% chorych — większej odpowiedzi cytogenetycznej. Wykazano w nim tak$\dot{z}$ e, że zastosowanie dazatynibu w znaczący sposób wpływa na zmniejszenie ilości transkryptu $B C R$ - $A B L 1$ we krwi ( $66 \%$ wyjściowo; $2,6 \%$ po 9 miesiącach terapii). Po 5 miesiącach trwania badania przewidywane PFS i OS oceniono na, odpowiednio, 90\% i $96 \%$. Podobna ocena przeprowadzona po 6 latach w grupie osób otrzymujących dazatynib w dawce $100 \mathrm{mg} /$ dobę wykazała jednak, że MMR uzyskuje jedynie $43 \%$ chorych. Także PFS oraz OS okazały się niesatysfakcjonujące (odpowiednio $49 \%$ i $71 \%$ ). Podobnie skumulowany odsetek progresji do faz bardziej zaawansowanych lub zgonu oceniono na $24 \%$ [22]. Dane te potwierdzają konieczność bardzo skrupulatnego monitorowania odpowiedzi u pacjentów z nietolerancją/nieskutecznością IM leczonych za pomocą TKI II generacji [1]. Niezwykle ważna w tym kontekście jest również analiza przyczyn odpowiedzi nieoptymalnej, w tym określenie, czy powodem braku skuteczności TKI II generacji jest nierealizowanie przez pacjenta zaleceń lekarskich odnośnie stosowania leku, nietolerancja TKI czy te $\dot{z}$ wystąpienie niemutacyjnej lub mutacyjnej oporności na TKI.

Najwięcej problemów terapeutycznych sprawiają chorzy, u których stwierdzono nieskuteczność następujących po sobie dwóch linii leczenia [23]. Zastosowanie TKI II generacji w tych przypadkach jest obarczone dużym ryzykiem nieskuteczności terapii. Średni czas do wystąpienia objawów jej niepowodzenia (przeżycie wolne od niepowodzenia terapii [FFS, failure-free survival]) wynosi tylko 20 miesięcy, a u osób $z$ objawami progresji do faz bardziej zaawansowanych - zaledwie 3-5 miesięcy [24].

W prezentowanym przypadku niepowodzenie terapii spowodowała obecność mutacji H396P genu $B C R-A B L 1$ w komórkach CML, która jest niewrażliwa na nilotynib. $\mathrm{W}$ badaniach in vitro wykazano, że dazatynib jest skuteczny w przypadkach obecności wielu mutacji wysoce opornych na IM i nilotynib, w tym mutacji H396P onkogenu $B C R-A B L 1$ [13, 14]. W opisywanym przypadku zastosowanie dazatynibu, wykazującego efekt inhibitorowy wobec mutanta w warunkach in vitro, umożliwiło uzyskanie CCyR, a następnie głębokiej odpowiedzi molekularnej. Potwierdza to celowość wykonywania badania na obecność mutacji KD $B C R-A B L 1$ przed podjęciem decyzji o kolejnej linii terapii u chorych opornych na określony TKI II generacji. Nie można wykluczyć, że w prezentowanym przypadku oporność na IM miała również charakter mutacyjny. Wiadomo bowiem, że w warunkach presji selekcyjnej może dochodzić do wzrostu klonów opornych na stosowany lek. Przy obniżonej wrażliwości mutanta(ów) na stosowany TKI narastanie oporności może mieć charakter powolny — aż do całkowitej dominacji klonu opornego na TKI, z klinicznymi i laboratoryjnymi objawami progresji [25].

Ostatnio udowodniono, że u chorych leczonych TKI można wykryć obecność defektów $B C R$ $-A B L 1$ w niskim mianie metodą sekwencjonowania następnej generacji (NGS, next generation sequencing) jeszcze przed pojawieniem się objawów nieskuteczności terapii. Technika ta jest o wiele bardziej czuła niż tradycyjne sekwencjonowanie. 
Z powodu wysokiej czułości nie jest ona jednak obecnie rekomendowana do monitorowania terapii TKI, gdyż umożliwia wykrycie zmian nieistotnych $z$ punktu widzenia klinicznego, nieodpowiadających za oporność/progresję choroby na ocenianym etapie terapii [26]. W praktyce jednak regularne monitorowanie odpowiedzi molekularnej metodą ilościowej reakcji łańcuchowej polimerazy (PCR, polymerase chain reaction), a także ocena obecności zaburzeń molekularnych onkogenu $B C R-A B L 1$ metodą sekwencjonowania wraz $z$ odpowiednim wyborem TKI umożliwiają przełamanie oporności mutacyjnej i uzyskanie głębokiej odpowiedzi molekularnej. Wykazano ostatnio, że jest to możliwe w przypadkach chorych leczonych nilotynibem $z$ powodu niepowodzenia poprzedzającej terapii za pomocą IM [27]. Wydaje się to możliwe także w przypadku odpowiedniego prowadzenia terapii 3. linii. Potwierdza to przebieg odpowiedzi na dazatynib u opisanego chorego opornego na dwie poprzedzające linie leczenia.

\section{Piśmiennictwo}

1. Baccarani M., Deininger M.W., Rosti G. i wsp. European LeukemiaNet recommendations for the management of chronic myeloid leukemia: 2013. Blood 2013; 122: 872-884.

2. Hochhaus A., Baccarani M., Deininger M. i wsp. Dasatinib induces durable cytogenetic responses in patients with chronic myelogenous leukemia in chronic phase with resistance or intolerance to imatinib. Leukemia 2008; 22: 1200-1206.

3. Kantarjian H., Pasquini R., Levy V. i wsp. Dasatinib or high-dose imatinib for chronic-phase chronic myeloid leukemia resistant to imatinib at a dose of 400 to 600 milligrams daily: two-year follow-up of a randomized phase 2 study (START-R). Cancer 2009; 115: 4136-4147.

4. Kantarjian H.M., Giles F.J., Bhalla K.N. i wsp. Update on imatinib-resistant chronic myeloid leukemia patients in chronic phase (CML-CP) on nilotinib therapy at 24 months: clinical response, safety, and long-term outcomes. Blood 2009; 114: abstrakt 1129.

5. Kantarjian H.M., Giles F.J., Bhalla K.N. i wsp. Nilotinib is effective in patients with chronic myeloid leukemia in chronic phase after imatinib resistance or intolerance: 24-month follow-up results. Blood 2011; 117: 1141-1145.

6. Apperley J. Part I: mechanisms of resistance to imatinib in chronic myeloid leukaemia. Lancet Oncol. 2007; 8: 1018-1029.

7. Melo J.V., Barnes D.J. Chronic myeloid leukaemia as a model of disease evolution in human cancer. Nat. Rev. Cancer 2007; 7: 441-453.

8. Naka K., Hoshii T., Tadokoro Y. i wsp. Molecular pathology of tumor-initiating cells: lessons from Philadelphia chromosome-positive leukemia. Pathol. Int. 2011; 61: 501-508.

9. Burchert A. Maintaining low BCR-ABL signaling output to restrict CML progression and enable persistence. Curr. Hematol. Malig. Rep. 2014; 9: 9-16.

10. Jabbour E., le Coutre P.D., Cortes J. i wsp. Prediction of outcomes in patients with $\mathrm{Ph}+$ chronic myeloid leukemia in chronic phase treated with nilotinib after imatinib resistance/intolerance. Leukemia 2013; 27: 907-913.

11. Dostępne na: http://www.nccn.org/professionals/physician_gls/ /PDF/cml.pdf. Data dostępu 12.01.2015.

12. Sacha T., Lewandowski K., Hellmann A. i wsp. Rekomendacje PALG dotyczące diagnostyki i leczenia przewlekłej białaczki szpikowej w 2013 r. Acta Haematol. Pol. 2013; 44: 345-362.

13. Tokarski J.S., Newitt J.A., Chang C.Y.J. i wsp. The structure of dasatinib (BMS-354825) bound to activated ABL kinase domain elucidates its inhibitory activity against imatinib-resistant $\mathrm{ABL}$ mutants. Cancer Res. 2006; 66: 5790-5797.

14. Aguilera D.G., Tsimberidou A.M. Dasatinib in chronic myeloid leukemia: a review. Ther. Clin. Risk Manag. 2009; 5: 281-289.

15. Redaelli S., Piazza R., Rostagno R. i wsp. Activity of bosutinib, dasatinib, and nilotinib against 18 imatinib-resistant BCR/ABL mutants. JCO 2009; 27: 469-471.

16. Weisberg E., Manley P., Mestan J. i wsp. AMN107 (nilotinib): a novel and selective inhibitor of BCR-ABL. Br. J. Cancer 2006; 94: 1765-1769.

17. Saglio G., Radich J., Kim D. i wsp. Response to nilotinib in chronic myelogenous leukemia patients in chronic phase (CML-CP) according to BCR-ABL mutations at baseline. ASCO 2008: abstrakt 7060 .

18. Schnittger S., Bacher U., Dicker F. i wsp. Associations between imatinib resistance conferring mutations and Philadelphia positive clonal cytogenetic evolution in CML. Genes Chromosomes Cancer 2010; 49: 910-918.

19. le Coutre P.D., Giles F.J., Pinilla-Ibarz J. i wsp. Nilotinib in imatinib-resistant or -intolerant patients (pts) with chronic myeloid leukemia in chronic phase (CML-CP): 48-month follow-up results of a phase 2 study. Blood 2011; 118: abstrakt 3770.

20. Giles F.J., le Coutre P.D., Pinilla-Ibarz J. i wsp. Nilotinib in imatinib-resistant or imatinib-intolerant patients with chronic myeloid leukemia in chronic phase: 48-month follow-up results of a phase II study. Leukemia 2013; 27: 107-112.

21. Jabbour E.J., Cortes J.E., Kantarjian H.M. Resistance to tyrosine kinase inhibition therapy for chronic myelogenous leukemia: a clinical perspective and emerging treatment options. Clin. Lymphoma Myeloma Leuk. 2013; 13: 515-529.

22. Shah N.P., Guilhot F., Cortes J.E. i wsp. Long-term outcome with dasatinib after imatinib failure in chronic-phase chronic myeloid leukemia: follow-up of a phase 3 study. Blood 2014; 123: 2317-2324.

23. Lipton J.H., Bryden P., Sidhu M.K. i wsp. Comparative efficacy of tyrosine kinase inhibitor treatments in the third-line setting, for chronic-phase chronic myelogenous leukemia after failure of second-generation tyrosine kinase inhibitors. Leuk. Res. 2015; 39: 58-64.

24. Garg R.J., Kantarjian H., O'Brien S. i wsp. The use of nilotinib or dasatinib after failure to 2 prior tyrosine kinase inhibitors: long-term follow-up. Blood 2009; 114: 4361-4368.

25. Ernst T., Erben P., Müller M.C. i wsp. Dynamics of BCR-ABL mutated clones prior to hematologic or cytogenetic resistance to imatinib. Haematologica 2008; 93: 186-192.

26. Machova Polakova K., Kulvait V., Benesova A. i wsp. Next-generation deep sequencing improves detection of BCR-ABL1 kinase domain mutations emerging under tyrosine kinase inhibitor treatment of chronic myeloid leukemia patients in chronic phase. J. Cancer Res. Clin. Oncol. 2015; 141: 887-899.

27. Hughes T.P., Lipton J.H., Spector N. i wsp. Deep molecular responses achieved in patients with CML-CP who are switched to nilotinib after long-term imatinib. Blood 2014; 124: 729-736. 